\title{
Perception of People Living with HIV/AIDS on Social Stigma of HIV/AIDS in Sukoharjo District
}

\author{
Persepsi Orang dengan HIV/AIDS terhadap Stigma HIV/AIDS Masyarakat \\ di Kabupaten Sukoharjo
}

Titik Haryanti, Wartini

Faculty of Public Health, University of Veteran Bangun Nusantara, Sukoharjo, Indonesia

\begin{abstract}
The negative social perception of people infected with HIVIAIDS is one obstacle to successful HIVIAIDS prevention and control in Sukoharjo District. This study aimed to examine the relationship between causative factors and duration of suffering from HIVIAIDS and negative perception and social stigma for people living with HIVIAIDS (PLWHA) in Sukoharjo District. This study used an analytical descriptive method with a cross-sectional approach. The study population was 256 PLWHA through April 2016, with a sample of 156 people using a quota sampling technique. Bivariate analysis with chi-square test and multivariate analysis with linear regression were conducted. Results showed that most respondents were $30-40$ years old $(69.2 \%)$, male (60.9\%), secondary school graduates (44.2\%), private employees (30.8\%), suffering from HIVIAIDS less than 5 years (66.7\%), affected by HIVIAIDS because of free sex (55.8\%), and having negative perceptions about the social stigma of HIVIAIDS $(67.9 \%)$. Statistical testing showed that age $(p$-value $=0.001)$ and the last education $(p-$ value $=0.015$ ) were related to negative perception and social stigma about PLWHA. Multiple regression testing indicated that age and the last education level of respondents both influenced their perceptions, but education level was more influential than age.
\end{abstract}

Keywords: HIVIAIDS, HIVIAIDS stigma, perception of people living with HIVIAIDS

\begin{abstract}
Abstrak
Persepsi negatif masyarakat terhadap orang yang terkena HIVIAIDS merupakan salah satu penghambat pencegahan dan penanggulangan HIVIAIDS di Kabupaten Sukoharjo. Penelitian ini bertujuan mengetahui hubungan karakteristik, faktor penyebab dan lamanya menderita HIVIAIDS dengan persepsi orang dengan HIVIAIDS (ODHA) terhadap stigma HIVIAIDS masyarakat di Kabupaten Sukoharjo. Penelitian ini menggunakan metode deskriptif analitik dengan pendekatan potong lintang. Populasi penelitian sebesar 256 ODHA sampai April 2016 dengan jumlah sampel berjumlah 156 orang dengan teknik quota sampling. Analisis bivariat dengan uji kai kuadrat dan analisis multivariat dengan regresi linier. Hasil penelitian menunjukkan bahwa sebagian besar responden berusia $30-40$ tahun $(69,2 \%)$, berjenis kelamin laki-laki $(60,9 \%)$, pendidikan menengah $(44,2 \%)$, pegawai swasta $(30,8 \%)$, lama menderita HIVIAIDS kurang dari 5 tahun $(66,7 \%)$, terkena HIVIAIDS karena seks bebas (55,8\%), dan memiliki persepsi negatif terhadap stigma HIVIAIDS masyarakat (67,9\%). Uji statistik menunjukkan bahwa usia (nilai $p=0,001$ ) dan pendidikan terakhir (nilai $p=0,015$ ) berhubungan dengan persepsi ODHA terhadap stigma HIV/AIDS masyarakat. Uji regresi berganda menunjukkan usia dan pendidikan terakhir responden keduanya berpengaruh terhadap persepsi mereka, tetapi pendidikan terakhir berpengaruh lebih besar dibandingkan usia.
\end{abstract}

Kata kunci: HIVIAIDS, stigma HIVIAIDS, persepsi orang dengan HIVIAIDS

How to Cite: Haryanti T, Wartini. Perception of people living with HIVIAIDS in Sukoharjo District. Kesmas: National Public Health Journal. 2019; 13 (3): 132-137. (doi:10.21109/kesmas.v13i3.1752)

\footnotetext{
Correspondence: Titik Haryanti, Faculty of Public Health University of Veteran Bangun Nusantara, Letjend. Sujono Humardhani Street No. 1, Jombor, Bendosari, Sukoharjo, Phone: +62271593156,E-mail: haryanti.titik@gmail.com Received: September $21^{\text {st }} 2017$

Revised: January $11^{\text {th }} 2018$

Accepted: April $11^{\text {th }} 2018$
} 


\section{Introduction}

HIV/AIDS is one of many global health problems. The spread of this deadly virus has threatened not only developed countries, but also developing countries such as Indonesia, including Sukoharjo District. The various risk factors for HIV/AIDS are free sex (risky), drug needle use, transmission through blood transfusion, and transmission from mother to child. In addition, the risk of HIV/AIDS transmission is marked by certain characteristics, such as age, occupation, and education.

From 1987, when it was first discovered, until June 2014, HIV/AIDS spread over 381 (76\%) of the 498 districts/cities in all provinces in Indonesia. The first province where an incident of AIDS was found was Bali in 1987. The number of AIDS cases reported in 2010 was 6,907 cases; 7,312 cases in $2011 ; 8,747$ cases in $2012 ; 6,266$ cases in 2013; and 1,700 cases in 2014 . The cumulative number of AIDS cases from 1987 to June 2014 totaled 55,623. The number of female AIDS patients was $28.9 \%$ and the number of male patients was $53.7 \%$, while $17.3 \%$ of the reported numbers did not reveal their gender. The highest percentage of HIV in 2014 was reported in the 25-49 age group (73.6\%), followed by the $20-24$ age group (14.9\%), followed by the age group older than 50 years $(5.3 \%)$. The $30-39$ age group had the highest percentage of AIDS at $37.7 \%$, while the 20-29 age group was $26 \%$, and the $40-49$ age group was $20.4 \% .^{1}$

Until 2014, of the cumulative HIV/AIDS cases in every province in Indonesia, the Central Java Province ranked the sixth with 12,799 cases, after DKI Jakarta, East Java, Papua, West Java, and Bali. However, from January-September 2014, the number of HIV/AIDS cases in the Central Java Province ranked the fourth, with 2,497 cases, after DKI Jakarta, West Java, and East Java. In 2010, the number of HIV/AIDS cases in Central Java was 874 cases; 1,276 cases in $2011 ; 1,404$ cases in 2012; 2,283 cases in 2013; and 1,775 cases in 2014. In 2012, the proportion of estimated populations vulnerable to the spread of HIV/AIDS in 2012 were as follows: direct sex workers' customers at $37.9 \%$; a couple of customers at $25.4 \%$; indirect sex workers' customers at $17.3 \%$; a couple of indirect sex workers' customers at $11.9 \%$; transvestites' customers at $4.6 \%$; direct sex workers and men who have sex with men (MSM) at $1.1 \%$; indirect sex workers at $0.8 \%$; injecting drug use (IDU) at $0.4 \%$; and a couple of IDU and transgenders at $0.2 \% .1$

The cumulative number of HIV/AIDS cases during the period from 1993 to April 2016 in Sukoharjo District was 256 cases, with the highest cumulative number in Kartasura Subdistrict $(16.8 \%)$. The cumulative incidence of HIV/AIDS occurred in the 30-40 age group (33.2\%), followed by the $20-30$ age group $(30.9 \%) .^{2}$

The less people understand the HIV/AIDS disease, the less effective the countermeasures program is, causing prevention efforts to slow. People still stigmatize HIV/AIDS patients, resulting in patients receiving discriminatory treatment. Social stigma and discrimination against people living with HIV/AIDS (PLWHA) not only worsens the patients' conditions, but also becomes a barrier for HIV/AIDS prevention and countermeasure programs. The negative perception, social stigma, and discrimination against PLWHA hinder the efforts to prevent and cure the disease.

The benefit of this study is discovering the relation of characteristics, causative factors, and duration of HIV/AIDS with the perception of PLWHA and its social stigma. One alternative is to focus HIV/AIDS prevention and countermeasure programs in Sukoharjo District, Central Java. This study aimed to determine the relation between the characteristics, length of suffering, and causes of social stigma based on the prevalence of HIV/AIDS in Sukoharjo District.

\section{Method}

This study used a descriptive study method by providing a picture of the state of the object under study treatment using a quantitative approach. A cross-sectional design was applied to make observations on the effects and the variables at the same time.

The population in this study included all HIV/AIDS patients in Sukoharjo District, which totaled 256 people. The study used the following sample formula: With $\mathrm{N}=$ 189 , $\mathrm{p}$-value $=0.513$ (Erledis study in 2010) and $d=$ 0.05 , the sample size in this study was 156 people selected by quota sampling. This is a sampling technique based on the availability of subjects to be observed that meet predetermined characteristics that are present early throughout the population. ${ }^{3}$

This study used an interview guide gauge to measure characteristics, causative factors, duration of HIV/AIDS, and perception of PLWHA on the social stigma of HIV/AIDS. The questionnaire consisted of five questions on the characteristics of HIV/AIDS patients, four questions on the causes of HIV/AIDS, and 12 questions on the perception of PLWHA on the social stigma of HIV/AIDS. Data were collected with the assistance of the peer support group chairman and student members of Citizens Care for AIDS (Warga Peduli AIDS), a NonGovernmental Organization in The Faculty of Public Health, University of Bangun Nusantara Sukoharjo, who received explanations and an equation for measuring perceptions related to the questionnaire.

There were four study variables: characteristics; causative factors; length of suffering from HIV/AIDS; and perception of PLWHA on social stigma of HIV/AIDS. Descriptive analysis was done to find out the description of characteristics, causative factors, and 
length of suffering from HIV/AIDS, and the perception of PLWHA on social stigma of HIV/AIDS. Bivariate analysis used chi-square testing, with alpha $=0.05$. Multivariate analysis used linear regression testing.

\section{Results}

Distribution of the respondents, showed $69.2 \%$ were aged $30-40$ years; $60.9 \%$ were male; $44.2 \%$ had secondary education; $30.8 \%$ were private sector employees; $66.7 \%$ had suffered from HIV/AIDS for less than five years; $55.8 \%$ suffered from HIV/AIDS because of free sex; and $67.9 \%$ had a negative perception on the social stigma of HIV/AIDS (Table 1).

As seen in Table 2, most of the categories, including age, sex, education, occupation, length of suffering, and causative factors, show a negative perception against the social stigma of HIV/AIDS. The statistical test showed a relation between age of respondents $(\mathrm{p}$-value $=0.001$ ) and latest education ( $\mathrm{p}$-value $=0.015)$, with social stigma of PLWHA ( $\mathrm{p}$-value $<0.05$ ). There was no relation between the sex $(p$-value $=0.585)$, occupation $(p$-value $=$ $0.453)$, length of suffering ( $\mathrm{p}$-value $=0.132)$, and causative factors of HIV/AIDS ( $p$-value $=0.285$ ) with the perception of PLWHA against social stigma of HIV/AIDS (p-value > 0.05).

Table 3 indicates a correlation between the PLWHA's perceptions on social stigma of HIV/AIDS and the age of respondents, with Pearson's correlation at 0.195, while the correlation between the PLWHA's perceptions on social stigma of HIV/AIDS and the education of respondents is 0.226 . Theoretically, because the correlation between the PLWHA's perceptions on social stigma of
HIV/AIDS and the education of respondents is greater, the variable of the respondent's education is therefore more influential to the PLWHA's perceptions on social stigma of HIV/AIDS compared with the respondent's age. The significance level of the correlation coefficient of an output side of the respondent's age with the PLWHA's perceptions on social stigma of HIV/AIDS resulted in a value of 0.007 , and the correlation of the respondents' education with the PLWHA's perceptions on social stigma of HIV/AIDS resulted in a value of 0.002 . Because the probability is under 0.05 , the correlation of the PLWHA's perceptions on social stigma of HIV/AIDS with age and education is real.The multivariate analysis showed an $\mathrm{R}$ square value of 0.63 , which means that $63 \%$ of the PLWHA's perceptions on social stigma of HIV/AIDS can be explained by age and education variables of respondents, while the remaining $37 \%$ is explained by other factors. From ANOVA or F test, the calculated $F$ value is 5.110 , with a significance level of 0.007 , meaning that a regression model can be used to predict the perception of PLWHA on social stigma of HIV/AIDS, or it can be said that age and education of respondents both influence the perception of PLWHA (p-value <0.05).

\section{Discussion}

According to Ministry of Health, until March 2017, a total of 242,699 people were reportedly infected with HIV, and the Central Java Province ranked the fifth nationally, with a percentage of $18.038 \%$. In addition, a total of 87,453 people were infected with AIDS, with the highest number falling in the age group of 20-29 years

Table 1. Distribution of Characteristics of People Living with HIV/AIDS

\begin{tabular}{|c|c|c|c|}
\hline Variable & Category & f & $\%$ \\
\hline \multirow[t]{3}{*}{ Age } & $<30$ years & 14 & 9 \\
\hline & $30-40$ years & 108 & 96.2 \\
\hline & $>40$ years & 34 & 3 \\
\hline \multirow[t]{2}{*}{ Sex } & Male & 95 & 60.9 \\
\hline & Female & 61 & 39.1 \\
\hline \multirow[t]{3}{*}{ Education } & High (diploma and bachelor degree) & 13 & 8.3 \\
\hline & Medium (junior and senior hig school) & 69 & 44.2 \\
\hline & Low (elementary school) & 74 & 47.4 \\
\hline \multirow[t]{7}{*}{ Occupation } & Unemployed & 18 & 11.5 \\
\hline & Housewife & 17 & 10.9 \\
\hline & Entrepreneur & 47 & 30.1 \\
\hline & Private employees & 48 & 30.8 \\
\hline & Civil servant & 2 & 1.3 \\
\hline & Farmer/labor & 22 & 14.1 \\
\hline & Student & 2 & 13.1 \\
\hline \multirow[t]{3}{*}{ The length of suffering from HIV/AIDS } & $<5$ years & 104 & 66.7 \\
\hline & $5-10$ years & 50 & 32.1 \\
\hline & $>10$ years & 2 & 1.3 \\
\hline \multirow[t]{3}{*}{ Causative factors of HIV/AIDS } & Free sex & 87 & 55.8 \\
\hline & Infected husband & 54 & 34.6 \\
\hline & Etc & 15 & 9.6 \\
\hline \multirow[t]{2}{*}{ Social stigma of people living with HIV/AIDS } & Positive & 50 & 32.1 \\
\hline & Negative & 106 & 67.9 \\
\hline
\end{tabular}


Table 2. Variables Associated with Perception of PLWHA

\begin{tabular}{|c|c|c|c|c|c|c|}
\hline \multirow{3}{*}{ Variable } & \multirow{3}{*}{ Category } & \multicolumn{4}{|c|}{ Perception of PLWHA } & \multirow{3}{*}{ p-Value } \\
\hline & & \multicolumn{3}{|c|}{ Negative $(n=106)$} & Positive $(n=50)$ & \\
\hline & & f & $\%$ & f & $\%$ & \\
\hline \multirow[t]{3}{*}{ Age } & $<30$ years & 8.0 & 57.1 & 6.0 & 42.9 & 0.001 \\
\hline & $30-40$ years & 83 & 76.9 & 25 & 23.1 & \\
\hline & $>40$ years & 15 & 44.1 & 19 & 55.9 & \\
\hline \multirow[t]{2}{*}{ Sex } & Male & 63 & 66.3 & 32 & 33.7 & 0.58 \\
\hline & Female & 43 & 70.5 & 18 & 29.5 & \\
\hline \multirow[t]{3}{*}{ Education } & High (diploma and bachelor degree) & 42 & 56.8 & 32 & 43.2 & 0.015 \\
\hline & Medium (junior and senior hig school) & 53 & 76.8 & 16 & 23.2 & \\
\hline & Low (elementary school) & 11 & 84.6 & 2.0 & 15.4 & \\
\hline \multirow[t]{2}{*}{ Occupation } & Unemployed & 27 & 73 & 10 & 27 & 0.453 \\
\hline & Employed & 79 & 66.4 & 40 & 33.6 & \\
\hline \multirow[t]{3}{*}{ The length of suffering from HIV/AIDS } & $<5$ years & 75 & 72.1 & 29 & 27.9 & 0.132 \\
\hline & $5-10$ years & 29 & 58 & 21 & 42 & \\
\hline & $>10$ years & 2.0 & 100 & 0 & 0 & \\
\hline \multirow[t]{3}{*}{ Causative factors of HIV/AIDS } & Free sex & 63 & 72.4 & 24 & 27.6 & 0.285 \\
\hline & Infected husband & 35 & 64.8 & 19 & 35.2 & \\
\hline & Etc & 8.0 & 53.3 & 7.0 & 46.7 & \\
\hline
\end{tabular}

Table 3. Final Model of Multivariate Analysis

\begin{tabular}{llrrr}
\hline & & PLWHA's Perception Category & Age of Respondents & Respondent's Education \\
\hline Pearson's Correlation & PLWHA's perception category & 1.000 & 0.195 & -0.226 \\
& Age of respondents & 0.195 & 1,000 & -0.433 \\
Sig. (1 tailed) & Respondent's education & -0.226 & -0.433 & 1,000 \\
& PLWHA's perception category & 0.007 & 0.007 & 0.002 \\
$\mathrm{~N}$ & Age of respondents & 0.002 & - & 0.000 \\
& Respondent's education & 156 & 156 & - \\
& PLWHA's perception category & 156 & 156 & 156 \\
& Age of respondents & 156 & 156 & 156 \\
\hline
\end{tabular}

Note: $\mathrm{N}=$ Number of sample

(31.4\%), followed by the age group of 30-39 years $(30.6 \%)$. This shows that HIV/AIDS cases are still dominated by the 20-39 age group, which means that most PLWHA are at childbearing age and active sexually. As viewed from male-dominated sex, this is supported by 2017 data from the Ministry of Health, which found the percentage of AIDS in males to be $56 \%$ and females to be $32 \%$, while $12 \%$ did not report their gender. As for risk factors, free sex was the biggest factor that causes the spread of HIV/AIDS. ${ }^{4}$ Referring to data from the Ministry of Health in 2017, risk factors for HIV/AIDS transmission are highest for heterosexuals $(68 \%)$, IDUs $(11 \%)$, homosexuals $(4 \%)$, and perinatal $(3 \%)$. Risk factors for heterosexuals include free-sex behavior and unsafe sexual intercourse between spouses because the husband has free-sex behavior or has sex with prostitutes. The transmission from husband to wife is one of the factors affecting the increase in HIV/AIDS cases among housewives. The highest number of AIDS patients is associated with occupation/private employee status, and the percentage of AIDS-infected housewives, at $12.302 \%$, is almost equal to the percentage of working mother patients. ${ }^{4}$

The issue of transmission from husbands to their wives through unsafe sexual intercourse and husbands at risk of suffering from HIV/AIDS due to free-sex behavior needs to be highlighted. Although the percentage of PLWHA coming from school/college students is low, this matter is a concern because this population has a long reproductive period. Consequently, the transmission risk is greater if no countermeasures or preventive actions are made to decrease the spread of HIV/AIDS. This is especially true if they practice deviant behaviors, such as free sex or drug use. The majority of HIV/AIDS cases suffered less than 5 years, meaning that most respondents are new patients.

The study also provided information on what respondents felt when they were first diagnosed with HIV/AIDS. Most respondents said they were shocked and did not believe that they had the condition. In fact, HIV-positive people often suffer from psychological problems, especially anxiety, depression, guilt, anger, and the urge to commit suicide. People infected with HIV/AIDS are often angered by the medical community's 
helplessness in finding a cure and an antidote for HIV/AIDS. This is aggravated by the fact that they also face public discrimination. ${ }^{5}$ A study by Pardita and Sudibia, ${ }^{6}$ revealed the differences found in the psychological condition of PLWHA in Denpasar; namely, they experienced higher levels of stress, frustration, anxiety, anger, denial, mourning, and shame after being diagnosed with HIV/AIDS. These psychological problems are usually experienced in the first years of an HIV diagnosis; hence a prolonged negative social stigma of HIV/AIDS can worsen the condition of people living with HIV.

The PLWHA's perception on the social stigma of HIV/AIDS remains negative, meaning that PLWHA feel that the community continues to stigmatize them. This aligns with Hermawati's ${ }^{7}$ study, which stated that PLWHA's perception on the social stigma of HIV/AIDS is mostly negative $(77.5 \%)$. The perception of PLWHA on the social stigma of PLWHA varies; that is, it can mean staying away from them because of narrow views and little knowledge about people living with HIV, incurable and highly contagious diseases, the worst illnesses, and assuming the illness is a punishment by God. ${ }^{8}$ Negative perceptions on social stigma of HIV/AIDS can affect the social life of PLWHA and their progression against the disease. The social stigma of PLWHA causes society to treat patients differently and to discriminate against them. Discrimination against PLWHA is an injustice to someone who has or is suspected of having HIV/AIDS. ${ }^{9}$ Stigma also prevents PLWHA from participating in social activities as they become introverted and less likely to interact with their families, friends, and neighbors. This behavior occurs because many people assume that PLWHA are people who misbehave, such as female sex workers, drugs users, and homosexuals, hence they reject and hate the group and any member of the group. ${ }^{10,11,12}$

Among the factors of respondent's characteristics, HIV/AIDS causes, and the length of suffering from HIV/AIDS associated with PLWHA's perception on social stigma of HIV/AIDS, only age and education are significantly related. According to Robbins, ${ }^{13}$ a person's perception of their own experience is related to one's age. This perception is further influenced by the individual's attitude toward the object of perception, the individual's own unfulfilled motives and desires, and experiences and expectations. The older someone is, the more life experience they have. In line with Robbins, ${ }^{13}$ it can be concluded that one's experience can affect perceptions about an object while the amount of experience is based on one's age. The older the PLWHA, the more positive the PLWHA's perception is on the social stigma of PLWHA. This is because of their life experience in solving life problems, including how to live with the social stigma of HIV/AIDS. Previous studies suggest a relation between age and stigma/discrimination experienced by PLWHA in South Africa, for example. ${ }^{14}$

A study by Hermawati, ${ }^{7}$ states that there is no real difference in PLWHA's perception on social stigma of HIV/AIDS between the two sample groups of males and females. This also aligns with Robbins', ${ }^{13}$ opinion, which states that sex does not affect a person's perception of an object. Although the PLWHA's perception of HIV/AIDS does not differ between male and female, the social stigma and discrimination experienced by women is more painful. A previous study stated that stigma and discrimination create psychological problems for patients, such as limited social life, low self-esteem, anxiety disorders, suicidal thoughts, and emotional distress based on their limited reception in healthcare facilities, thus worsening their health condition. ${ }^{15,16}$

A study by Li X et al. ${ }^{17}$ showed that education levels, including primary, secondary, and tertiary education, do not improve most respondents' negative perceptions on social stigma of HIV/AIDS. Another advanced study shows that a low education level creates a negative stigma against PLWHA. ${ }^{18,19}$ This study also found no significant difference between junior high school, senior high school, and diploma levels on the perception on social stigma of HIV/AIDS. This is probably due to PLWHA's inadequate knowledge of how HIV/AIDS is transmitted. Having inadequate knowledge about HIV/AIDS is very influential on the emergence of the social stigma of HIV/AIDS, and this is because many do not understand the mechanism of HIV/AIDS transmission. ${ }^{9}$ Any misunderstanding and inadequate knowledge about HIV/AIDS can cause people to be afraid of and more likely to reject PLWHA. ${ }^{9}$

Employment, length of suffering, and the causative factors of HIV/AIDS are not related to the PLWHA's perception on social stigma of HIV/AIDS. This aligns with the Hermawati's ${ }^{7}$, which states that there is no relation between the length of time one has HIV/AIDS and PLWHA's perception on social stigma of HIV/AIDS. This aligns with Davidoff's 20 study, which states that one's perception is not influenced by the duration of a chronic disease. Perceptions are influenced by expectations, desires, and motivations, whereas expectations are strongly influenced by habits, experiences, and judgment.

Multivariate tests showed that both age and education levels affect PLWHA's perception on the social stigma of HIV/AIDS. Education was more influential than age. The age and education factors account for the effect of PLWHA's perception on social stigma of HIV/AIDS by $63 \%$, while other factors account for $37 \%$. This is described by Waluyo, et al. ${ }^{21}$, who stated that PLWHA's perceptions on the social stigma of HIV/AIDS vary, such as staying away from the patient because of the community's limited view and knowledge of PLWHA, seeing it 
as a highly contagious disease with no cure, believing it is the worst disease, and believing that the sickness is a punishment by God. That study concluded that the social stigma of HIV/AIDS is more influenced by inadequate knowledge of the disease and how it is spread by the infected.

\section{Conclusion}

This study's results show that most of the respondents were males with secondary education, who are private employees. All the respondents were at the sexually active age of $30-40$ years old, with free sex as the biggest causative factor. Most of the respondents are new HIV/AIDS patients ( $<5$ years); hence, they have a negative perception on the social stigma of HIV/AIDS. Statistical analysis indicates a relation between age and education and the social stigma of HIV/AIDS. Multiple regression testing shows that age and education of respondents both influence PLWHA's perception on the social stigma of HIV/AIDS.

\section{References}

1. Departemen Kesehatan Republik Indonesia. Laporan pengembangan HIV/AIDS tahun 2014. Jakarta: Departemen Kesehatan Republik Indonesia; 2014.

2. Komisi Penanggulangan AIDS Kabupaten Sukohajo. Laporan perkembangan HIV/AIDS Kabupaten Sukoharjo tahun 2014. Sukoharjo: Komisi Penanggulangan AIDS Kabupaten Sukoharjo; 2014.

3. Sugiyono. Metode penelitian kuantitatif, kualitatif dan R\&D. Bandung: CV Alfabeta; 2010.

4. Kementerian Kesehatan Republik Indonesia. Laporan HIV/AIDS triwulan I tahun 2017. Jakara: Kementerian Kesehatan Republik Indonesia; 2017.

5. Hutapea R. AIDS \& PMS dan pemerkosan. Jakarta: Raja Gafindo; 2004.

6. Pardita DPY, Sudibia IK. Analisis dampak sosial, ekonomi, dan psikologis penderita HIV/AIDS di kota Denpasar. Jurnal Buletin Studi Ekonomi. 2014; 19(2): 193-6.

7. Hermawati P. Hubungan persepsi ODHA terhadap stigma HIV/AIDS masyarakat dengan interaksi sosial pada ODHA [Skripsi]. Jakarta: Universitas Islam Negeri Syarif Hidayatullah; 2011.
8. Waluyo A, Nurachmah E, Rosakawati. Persepsi pasien HIV/AIDS dan keluarganya tentang HIV/AIDS dan stigma masyarakat terhadap pasien. Jurnal Keprawatan Indonesia. 2006;10 (2): 61-9.

9. Herek GM, Capitanio JP, Widaman KF. HIV related stigma and knowledge in the United States: prevalence and trends, 1991-1999. American Journal of Public Health 2002; 92 (3): 371-7.

10. Darmoris. Diskriminasi petugas kesehatan terhadap orang dengan HIVAIDS (ODHA) di Rumah Sakit Provinsi Kepulauan Bangka Belitung [tesis]. Semarang: Universitas Diponegoro; 2011.

11. Guma J. Health workers stigmatise HIV and AIDS patients. South Sudan Medical Journal. 2011; 4: 92-3.

12. Sohn A, Park S. HIV/AIDS knowledge, stigmatizing attitudes, and related behaviors and factors that affect stigmatizing attitudes against HIV/AIDS among Korean adolescents. Osong Public Health and Research Perspectives. 2012; 3 (1): 24-30.

13. Robbins PS. Perilaku organisasi. Jakarta: Indeks Gramedia; 2006.

14. Santos MMd, Kruger P, Mellors SE, Wolvaardt G, Ryst Evd. An exploratory survey measuring stigma and discrimination experienced by people living with HIV/AIDS in South Africa: The people living with HIV stigma index. BMC Public Health. 2014; 14(80): 1-13.

15. Liamputttong P, Haritavorn N, Angsulee KN. HIV and AIDS, stigma and AIDS support groups: Perspectives from women living with HIV/AIDS in Central Thailand. Social Science and Medicine. 2009; 69(6): 862-8.

16. Thomas B, Nyamathi A, Swaminathan S. Impact of HIV/AIDS on mothers in Southern India: A qualitative study. AIDS and Behavior. 2009; 13: 989-96. 2009.

17. Li X, Yuan L, Li X, Shi J, Jiang L, Zhang C, et al. Factors associated with stigma attitude towards people living with HIV among general individuals in Heilongjiang, Northeast China. BMC Infectious Diseases. 2017; 17 (154): 1-8.

18. Chen J CM, Chen S, Zhang S. Community Environment and HIV/AIDS Related Stigma in China. AIDS Education and Prevention. 2005; 17(1): $1-11$.

19. Lau J, Tsui H. Surveillance of discriminatory attitudes toward people living with HIV/AIDS among the general public in Hong Kong from 1994 to 2000. Disability and Rehabilitation. 2003; 25(24):1354-60.

20. Davidoff LL. Psikologi suatu pengantar edisi Kedua jilid I. Jakarta: Gramedia; 1981.

21. Waluyo A, Nurachmah E, Rosakawati. Persepsi pasien HIV/AIDS dan 